\title{
Impact of parity, stage of lactation, and subclincal mastitis on the concentration of vitamin C in Shami camel milk
}

Razan Majed Semsmia ( $\square$ razan.semsmia@gmail.com )

University of Agriculture,Damascus, Syria https://orcid.org/0000-0002-9341-9243

tarek abed alrahim

Damascus University

Al Moatasem Bellah Al-Daker

Syrian Agriculture Research Center

\section{Research Article}

Keywords: Shami Camels, Milk, Vitamin C, Stage of Lactation, Parity, Subclinical Mastitis

Posted Date: November 1st, 2021

DOI: https://doi.org/10.21203/rs.3.rs-1011930/v1

License: (c) (i) This work is licensed under a Creative Commons Attribution 4.0 International License.

Read Full License 


\section{Abstract}

A study was conducted at Deir Al-Hajar Research Station for Shami Camels, Administration of Livestock Research, General Commission for Scientific Agricultural Research (GCSAR) in the years 2019 and 2020 to describe the associations between vitamin $\mathrm{C}$ concentrations in milk, and either stage of lactation, parity or the presence of mastitis. For this purpose, thirty lactating Shami camels from different parities were used. Milk samples were collected monthly over one entire lactation season lasting 11 months. The concentration of vitamin C was $35.01 \pm 9.81 \mathrm{mg} / \mathrm{l}$ milk and ranged between 33.01 and $36.80 \mathrm{mg} / \mathrm{L}$ milk during considered parities without significant differences in its concentration . However, vitamin $\mathrm{C}$ concentration was affected by lactation month $P<0.0 .5$, and the values ranged between 18.99 and 53.03 $\mathrm{mg} / \mathrm{l}$ milk during the course of lactation. An evident decline in vitamin $\mathrm{C}$ concentration in camel milk appeared with positive interactions for California test by $20-50 \%$. The average concentration of vitamin $C$ in milk produced from healthy and infected udders was $35.01 \pm 9.81 \mathrm{mg} / \mathrm{l}$ and $22.99 \pm 1.30 \mathrm{mg} / \mathrm{l}$, respectively.

\section{Introduction}

Vitamin C (ascorbic acid) is one of the water-soluble vitamins (Julijana et al., 2018), and its composition in mammals depends on glucose content in the liver (Comb, 2008). It is available in two forms of biological importance, one of which is reduced and called L-Ascorbic acid and is the most biologically active form, and the other is the oxidizing form L-dehydroascorbic acid, which has a biological value as well (Hernandez et al, 2006). In ruminants, as a result of the intense oxidation process in the rumen, a large part of vitamin $\mathrm{C}$ is converted to diketogulanic acid which has no vital functions, making them more susceptible to diseases associated with vitamin C deficiency such as scurvy and mastitis (MacLeod et al., 2003).

Camel milk has a relatively high content of vitamin $\mathrm{C}$ compared to that of other farm animals, and it is 35 times that of cow's milk, and this gives it a high nutraceutical value, especially for people living in desert areas (Stahl et al, 2006). The importance of this high content of this compound is due to it is a powerful antioxidant that prevents bacterial growth in milk and keeps it from spoilage (Wernery et al., 2013) as well as its important role in stimulating collagen protein secretion by hydrogenating lysine and proline amino acids (Jilo and Tegegne, 2016).

Vitamin C concentration in camel milk varies $15-435 \mathrm{mg} / \mathrm{l}$ (Konuspayeva et al., 2011), and this variation in vitamin $\mathrm{C}$ concentration is due to the effect of a number of factors such as the breed. Thus, vitamin $\mathrm{C}$ concentration in the milk of double-humped camel (Camelus bacterianus) was higher than those of dromedary (Camelus dromerdarius) and hybrid camels. These concentrations valued at 169, 146 and $133 \mathrm{mg} / \mathrm{l}$ in double-humped, dromedary and hybrids, respectively (Faye et al., 2008), in addition to other factors such as quality change of feed consumed per season (Haddadin et al., 2008) and stage of lactation, as the colostrum has a relatively high content of vitamin C compared to normal milk (Mal, 
2007). The health status of the udder is one of the most influential factors in the variation of vitamin $C$ content in camel milk by more than $45 \%$ (Mohamed et al., 2005).

\section{Objectives}

This study aims, in light of the foregoing, to study the effect of milk production month, parity, and subclincal mastitis on vitamin C level in the milk of Shami camels in order to establish an identity for vitamin C level, whether as an important indicator of health status of the udder or as a nutraceutical element of Shami camels in Syria.

\section{Materials And Methods}

\section{Study location and animals:}

The study was conducted at Deir Al-Hajar Research Station for Shami Camels of Livestock Research Administration at the General Commission for Scientific Agricultural Research during 2019 and 2020 seasons. It was carried out on 30 Shami milking camels at ages ranging 5-20 years from different milking seasons; from the first to the sixth parity, with an average of 5 animals in each group. Animals were selected at the end of gestation period and randomly from the original herd. Each animal group within one parity was approximately the same in weight and age.

\section{Feeding the study animals:}

Maintenance and production nutritional requirements were provided for the camels according to milk amount produced during milk production season until drying off. So camels were fed twice daily at 9.00 and 16.00 with concentrate ( barley, extracted cotton sead meal , bran, minerals and vitamins) and hay was provided in the evening. In addittion to grazing the animals daily on the fodder barley crop for 5 hours.

\section{Sheltering animals:}

Animals are housed freely in semi-open pens, where free water and concentrated feed are provided in two batches, morning and evening.

\section{Milk sampling:}

Milk samples (25) $\mathrm{ml}$ were taken from each camel separately at a rate of once a month until the end of milking season in the eleventh month approximately, after mixing the milk produced by manual milking. Vitamin $\mathrm{C}$ level in those samples was estimated.

\section{Estimation of Vitamin C:}

Vitamin C was estimated by chemical titration recommended by (Dabrowski and Hinterleitner, 1989) which is based on oxidation-reduction reactions using 2.6 chlorophenol indophenol dye in which ascorbic 
acid is oxidized to dehydrogenated ascorbic acid and the dye (blue color) is reduced to pink colour.

\section{Methodology:}

- Titration of milk sample: $5 \mathrm{ml}$ of milk sample is diluted by adding $15 \mathrm{ml}$ of $6 \%$ trichloroacetic acid, and then filtered. Later, $10 \mathrm{ml}$ of filtrate is taken and $10 \mathrm{ml}$ of $0.4 \%$ oxalic acid is added, then dyetitration is done until the appearance of pink colour.

- Titration of the control: A standard solution of vitamin C at concentration of $0.2 \mathrm{mg} / \mathrm{l}$ is prepared by dissolving $20 \mathrm{mg}$ of ascorbic acid in $100 \mathrm{ml}$ of oxalic acid at $0.4 \%$ concentration, then $10 \mathrm{ml}$ of that standard solution is taken and dye-titrated until the appearance of pink color. Titration is repeated three times for the sample and the control, and the average volume is taken. The concentration of ascorbic acid in the samples is calculated by the following relation:

\section{Ascorbic acid $\mathrm{mg} / \mathrm{l}$ = (average volume of dye consumed by sample / average volume of dye consumed by the control) $x$ concentration of the control}

California Mastitis Test (CMT): $1 \mathrm{ml}$ milk was placed in a test cup, $1 \mathrm{ml}$ California CMT test reagent (volume of milk = volume of reactant) was added and stirred well to mix milk with CMT reactant. The results were read according to (Schalm and Noorlander, 1957) method which was either:

- Negative: when the milk remains liquid and grey, so the milk is from udders not infected with mastitis.

- Positive with varying degrees: when there is a soft or thick sticky jelly, sticky lumps, or a gel of egg white texture with a change in color of milk between light violet pink and dark violet, and this implies that the milk is produced from udders infected with subclinical or clinical mastitis in varying degrees.

\section{Statistical analysis:}

The study indicators were compiled in special tables in Excel, and SPSS v.25 was used to perform the statistical analysis according to the general linear model. The least significant difference at confidence level 5\% (LSD 5\%) was estimated. The results were expressed as arithmetic mean $\mathrm{X} \pm$ standard deviation SD.

- The first model: $Y_{i j}=\mu+a_{i}+b_{j}+e_{i j}$

- the second model: $Y_{k}=\mu+v_{k}+e_{k}$

Where:

$\mathrm{Y}_{\mathrm{ij}}, \mathrm{Y}_{\mathrm{k}}$ : Studied characteristic (vitamin C concentration)

$\mu:$ General average of the characteristic studied

a: Effect of i parity 1 to 6 
b: Effect of the month $\mathrm{j}$ the number of the month from 1 to 11

$\mathrm{v}$ : Degree of california mastitis test $\mathrm{k}$ from 0 to 3

eij , $e_{k}$ : Experimental error

\section{Results}

\section{General average of vitamin C:}

The average concentration of vitamin $C$ in milk produced from healthy udders was $35.01 \pm 9.81 \mathrm{mg} / \mathrm{l}$, and ranged between $18.99-53.03 \mathrm{mg} / \mathrm{l}$ milk during its measurement period. Its average concentration in camel milk that showed positive reactions to California test was $22.99 \pm 1.30 \mathrm{mg} / \mathrm{l}$.

\section{Analysis of variance for vitamin C:}

The results of the analysis of variance in Table No. $(1)$ revealed a significant effect $(P<0.05)$ for milk production stage and health status of the udder on average concentration of vitamin $\mathrm{C}$.

Table 1- Analysis of variance for vitamin C

\begin{tabular}{|l|c|c|c|c|}
\hline \multicolumn{1}{|c|}{ Variance sources } & Degree of freedom & $\begin{array}{c}\text { Average sum of deviation squares } \\
\text { M.M.S }\end{array}$ & $\begin{array}{c}\text { LSD } \\
\text { Experimental error } \\
\text { SE }\end{array}$ & - \\
\hline Milking season & 5 & 1.16 & 0.54 & \\
\hline Health status of udder & 4 & $1356.42^{*}$ & 1.06 & 1.65 \\
\hline
\end{tabular}

* Implies that there is a significant difference at level $\mathrm{P}<0.05$.

\section{The effect of parity on vitamin $\mathrm{C}$ concentration:}

Table (2) shows vitamin C concentration by considered lactation season. It is noticed that there is a nonsignificant increase in vitamin $\mathrm{C}$ concentration with the advancement of studied lactation seasons, and the values reached 33.01 and $36.80 \mathrm{mg} / \mathrm{l}$ in the first and sixth seasons, respectively.

Table 2-Vitamin C concentration $(\mathrm{mg} / \mathrm{l} \pm \mathrm{SD}$ ) from the first to sixth parity 


\begin{tabular}{|c|c|}
\hline Parity & X \pm SD \\
\hline 1 & $33.01 \pm 10.05$ \\
\hline 2 & $33.83 \pm 9.90$ \\
\hline 3 & $34.79 \pm 9.81$ \\
\hline 4 & $35.49 \pm 9.74$ \\
\hline 5 & $36.15 \pm 9.67$ \\
\hline 6 & $36.80 \pm 9.60$ \\
\hline
\end{tabular}

\section{The effect of milk production month on vitamin C concentration:}

Table (3) shows vitamin $\mathrm{C}$ concentration by milk production month. It is noticeable that there is a significant change $\mathrm{P}<0.05$ in vitamin $\mathrm{C}$ concentration by milk production month, where the highest value reached $53.03 \mathrm{mg} / \mathrm{l}$ in the first month and the lowest was $18.99 \mathrm{mg} / \mathrm{l}$ in the sixth month of milk production season.

Table 3- Vitamin C concentration (mg/l \pm SD) by milk production month

\begin{tabular}{|c|c|}
\hline Milk production month & $\mathrm{X} \pm \mathrm{SD}$ \\
\hline 1 & $53.03^{\mathrm{k}} \pm 1.70$ \\
\hline 2 & $33.14^{\mathrm{e}} \pm 2.32$ \\
\hline 3 & $31.90^{\mathrm{d}} \pm 2.57$ \\
\hline 4 & $25.04^{\mathrm{c}} \pm 1.13$ \\
\hline 5 & $22.25^{\mathrm{b}} \pm 1.20$ \\
\hline 6 & $18.99^{\mathrm{a}} \pm 1.90$ \\
\hline 7 & $41.69^{\mathrm{i}} \pm 1.20$ \\
\hline 8 & $44.53^{\mathrm{j}} \pm 0.93$ \\
\hline 9 & $36.03^{\mathrm{f}} \pm 0.58$ \\
\hline 10 & $38.05^{\mathrm{g}} \pm 0.67$ \\
\hline 11 & $40.50^{\mathrm{h}} \pm 0.82$ \\
\hline
\end{tabular}

Figures with different letters within the same column indicate significant differences at 5\% level using LSD test.

\section{The effect of health status of the udder on vitamin $\mathrm{C}$ concentration:}

Table (4) shows variation in vitamin C content according to the results of California test that was conducted on all milk samples collected in order to detect subclinical mastitis of milking camels.

Table 4- Vitamin C concentration (mg/l \pm SD) in experimental animals based on California test scores 


\begin{tabular}{l|c|c|c|}
\hline Milk texture & Symbol & Interaction & X \pm SD \\
\hline Unchanged & O & Negative & $35.02^{\mathrm{a}} \pm 9.81$ \\
\hline Formation of a light viscous residue that disappears with continuous movement & T & Impact & $30.09^{\mathrm{b}} \pm 0.46$ \\
\hline $\begin{array}{c}\text { Formation of a distinct, separate mucus residue that disappears with continuous } \\
\text { movement }\end{array}$ & +1 & Poor & $24.50^{\mathrm{c}} \pm 0.70$ \\
\hline $\begin{array}{c}\text { Direct thickening of the mixture with the appearance of a symptom of gel formation } \\
\text { Jelly (convex gel form) }\end{array}$ & +2 & Apparent & $21.90^{\mathrm{d}} \pm 0.80$ \\
\hline & +3 & Strong & $17.52^{\mathrm{e}} \pm 0.42$ \\
\hline
\end{tabular}

Figures with different letters within the same column indicate significant differences at $5 \%$ level using LSD test.

\section{Discussion}

The average concentration of vitamin $\mathrm{C}$ in camel milk was about $35.01 \pm 9.81 \mathrm{mg} / \mathrm{l}$, and it corresponds to that of some other international studies carried out on single-humped camel milk. Average concentration reached $34.16 \mathrm{mg} / \mathrm{l}$ in (Farah et al., 1994) and 15-60 mg/l (Farah, 1993), while it was about $40.9 \mathrm{mg} / \mathrm{l}$ (Stahl et al., 2006). Lactation season number did not significantly affect its concentration, and its level remained normal ranging between $33.01 \mathrm{mg} / \mathrm{l}$ and $36.80 \mathrm{mg} / \mathrm{l}$, and this was also shown by (Dowelmadina et al., 2018) on the Arabian camel in Sudan.

The results showed that the highest concentration of vitamin $\mathrm{C}$ in camel milk was in the first month of lactation season. This was also stated by (Sahani et al., 1998) reporting that the first stage of lactation season is associated with high vitamin $\mathrm{C}$ content in the milk of considered camels, and this may be due to the fact that milk is an essential source to meet the newborns needs of this element during that age stage. It was also found that the newborns are not able to synthesize vitamin $\mathrm{C}$ with high self-efficacy until they reach 4-week age (Hidiroglou et al., 1995).

It should also be noted that vitamin C content decreased significantly during the period extending from the fourth to the sixth month, and this may be due to the increase in milk produced during that stage of milk production season and got the same result (Konuspayeva et al., 2011). In Kazakhstan, on different breeds of camels, the lowest concentrations of vitamin C were recorded in spring, when milk production reached its highest levels. There are also similar results (Mohamed and Al-Rasheedi, 2013) on Anafi camel breed in Sudan, where milk production declined in dry seasons and as milk production advanced, in turn, leading to an increase in vitamin $\mathrm{C}$ concentrations in the considered camel milk compared to those in the wet seasons. This may be due to the fact that vitamin C composition depends on D-glucose or D-galactose through glucuronic acid cycle. The demand for sugar lactose increases in high-producing animals for increasing milk production, affecting negatively vitamin $\mathrm{C}$ content of milk (Radostits et al., 1994). 
It is noticeable that the concentration of vitamin C decreased by $20-50 \%$ in the milk samples that showed positive results for California test compared with those that gave negative reactions during the same season and stage of milk production. This result is in line with that of (Mohamed et al., 2005) on the Arabian camel in Sudan, where there are significant differences in vitamin $\mathrm{C}$ content in camel milk according to the health status of the udder, and its average concentration reached $47.4 \mathrm{mg} / \mathrm{l}$ in the milk produced from healthy udders versus $26.8 \mathrm{mg} / \mathrm{l}$ in the milk produced from udders infected with mastitis. In another study conducted on Indian cows to reveal the relationship between vitamin $\mathrm{C}$ concentration and health status of the udder, it was found that the animals showing clinical or subclinical symptoms of mastitis when treated by injecting doses of vitamin $\mathrm{C}$ under the skin for 5 consecutive days (at the rate of $25 \mathrm{mg}$ ascorbic acid/kg live weight), the health status of their udder has improved with an efficiency exceeding that of antibiotics (Naresh et al., 2002). Researchers think that high concentrations of vitamin $C$ have an important role in activating the defensive neutrophil functions in terms of migration, union, phagocytosis and extermination, as it is a powerful antioxidant capable of donating an electron, thus neutralizing the highly electronegative free radicals released by neutrophils while performing their defensive functions (Wolf, 1993).

\section{Conclusions And Recommendations}

- Vitamin C concentration was within the common normal limits, and rose at early lactation season.

- It is possible to benefit from camel milk at early lactation season, as vitamin C concentrations are high, whether for nutrition or treatment of some diseases.

- The level of vitamin C in milk is a key indicator to predict udder health udder status

- Implementing studies concerning Shami camels on the potential for treating udders infected with clinical or subclinical mastitis with vitamin C.

\section{Declarations}

\section{Acknowledgments}

Thanks for the General Commission for Scientific Agricultural Research (Syria), for its supporting and funding this research

\section{Conflict of Interest Statement}

All the authors have no conflict of interest.

\section{Data availability}

All the data have been included in the submitted manuscript.

Competing Interests: The funding of this research was by General Commission for Scientific Agricultural Research (Syria). 


\section{References}

CombsG F.(2008). Vitamin C. In: The vitamins: fundamental aspects in nutrition and health, third edition (Ed. G. F. Combs) Academic Press, San Diego, CA, USA. pp. 235-263.

Dabrowski K. Hinterleitner S. (1989).Applications of a simultaneous assay of ascorbic acid, Dehydroascorbic acid and ascorbic sulphate in biological materials. Analyst. (114): 83-87.

Dowelmadinaz I M M, Zubier E M E, Abakar A D O.(2018). Variability of vitamins (A,E, and C) levels in Arabian camel milk in Sudan," Journal of Global Agriculture and Ecology, 7(4): 138-144.

Farah Z. (1993). Composition and characteristics of camel milk. Journal of Dairy Research. 60: 603-626

FarahZ, Rettenmaier R, Atkins D. (1994). Vitamin content in camel milk. International Journal for Vitamin and Nutrition Research, 62:30-33.

Faye B, Konuspayeva G, Messad S , Loiseau G. Discriminant milk components of Bactrian camel (Camelus bactrianus), dromedary (Camelus dromedarius) and. hybrids (2008). Dairy Sci. Technol, 88: 607617.

Haddadin M S, Gammoh S I, Robinson R K. (2008). Seasonal variations in the chemical composition of camel milk in Jordan,. J. Dairy. Res, 75(1): 8-12.

Hernandez Y, Lobo M. Gonzalez G M. (2006) Determination of vitamin C in tropical fruits: A comparative evaluation of methods," Food Chemistry, 96: p 654-664.

Hidiroglou M, . Ivan M, Batra T. (1995) .Concentrations of vitamin C in plasma and milk of dairy cattle, Ann Zootech, 44: 399-402

JiloanaK, Tegegne D. "Chemical Composition and Medicinal Values of Camel Milk,(2016). International Journal of Research Studies in Biosciences (IJRSB), 4(4): 13-25.

JulijanaT. Menkovska M, Ahmad M A. Determination of Vitamin C in Different Types of Milk. (2018). The International Journal of Engineering and Science, 7(5): 77-82.

Konuspayeva G, Faye B, Loiseau G., (2011). Variability of vitamin C content in camel milk from Kazakhstan," Journal of Camelid Science, 4: 63-69

MacLeod D, Ozimeck L, Kennelly J. J, Supplemental vitamin C may enhance immune function in dairy cows. (2003) In: Proceedings of Western Canadian Dairy Seminar.

Mal G. Chemical composition and vitamin C content of milk in Indian camels managed under farm conditions,(2007). Indian Veterinary Journal, 77:695-696 
Mohamed HE , Al-Rasheedi AD. (2013) .Factors affecting vitamin C contents of camel Milk. Journal of Camel Practice and Research, 20(1):45-46. .

Mohamed H. E, Mousa H. M, Beynen, A. C.(2005). Ascorbic acid concentrations in milk from Sudanese camels," J. Anim. Physiol. and Anim, Nut. 89: 35-37.

Naresh R., Dwivedi S , Swarup D, Patra R. (2002). Evaluation of Ascorbic Acid Treatment in Clinical and Subclinical Mastitis of Indian Dairy Cows,. Asian. Aust. J. Anim. Sci, 15(6)Z 905-911.

Radostits OM , Blood D C, Gay C C. (1994). Veterinary Medicine,. Bailliere Tindall, London

Sahani M. S, Rathinasabapathy M, Gorakhmal N, Khanna D. (1998) Milking technique and other factors affecting milk production potential in different breeds of camels under farm conditions. Indian Journal of Animal Science, 68: 254-256.

Schalm OW, Noorlander D O. (1957). Experiments and observations leading to development of California mastitis Test," J. Am. Vet. Med. Asso, 130:199-204.

StahlT., Duehlmeier H. P R., Wernery U. (2006). Selected vitamins and fatty acid patterns in dromedary milk and colostrum. Journal of Camel Practice and Research, 13, 53-57,

WerneryU R, Masko O B, Johnson B O, Jose SA, Nagy H. P, Lorenzen PCH.(2013). Lactoperoxidase: a suitable enzymatic marker of camel milk pasteurization, Journal of Camel Practice and Research, 20(1):35-38

Wolf G. Uptake of ascorbic acid by human neutrophils Nutr. Rev.(1993) 51:337-338. 